\section{Dynamics of Online Relationship Marketing: Relationship Quality and Customer Loyalty in Iranian banks}

\author{
Akram Garepasha ${ }^{1}$ \\ Samad Aali ${ }^{1}$ \\ Alireza Bafandeh Zendeh" \\ Soleyman Iranzadeh ${ }^{1}$ \\ ${ }^{1}$ Department of Management, Tabriz Branch, Islamic Azad University, Tabriz, Iran
}

Received on

02/19/2018

Approved on

08/21/2019

\section{Responsible editor:}

Prof.Dr.Francisco Liébana-

Cabanillas

Evaluation process:

Double Blind Review

\begin{abstract}
Purpose - The purpose of this paper is to show the dynamics of relationship marketing in e-banking by examining the association between relationship quality and online customer loyalty at different stages of the relationship lifecycle.

Design/methodology/approach - A sample of 651 customers of Iranian banks in East Azerbaijan Province who had used online banking services was selected for the study after completing a questionnaire. The research hypotheses were tested using structural equation modeling and the AMOS23 software.
\end{abstract}

Findings - The results showed that the level of the customer relationship determines the effect of relationship quality on customer loyalty in e-banking. Specifically, the effect of online commitment on customer loyalty decreases over time. In addition, as the relationship develops between the customer and the business, the influence of online trust on loyalty increases.

Originality/value - The main contribution of this paper is it enriches the relationship marketing literature with respect to the dynamics of relationships by challenging the effectiveness of relationship marketing, especially the use of the same relational constructs (online satisfaction, trust, and commitment) for customers at different stages of the relationship lifecycle.

Keywords - dynamic relationship marketing; online relationship quality; online loyalty; relationship lifecycle; e-banking

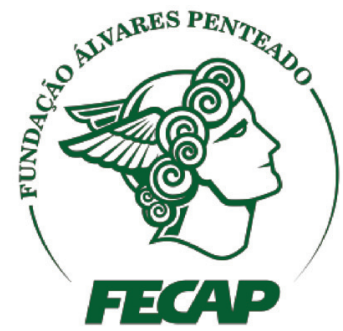

Review of Business Management

DOI:10.7819/rbgn.v22i1.4043 


\section{Introduction}

The rise of internet commerce in the 1990s and its ever-increasing growth have been accompanied by tremendous developments in business environments, compelling firms to fight for survival in the highly competitive environment by entering electronic markets and adapting to the new conditions (Elliot, 2007). In addition, despite the rapid development of internet commerce and the need for businesses to enter the electronic market, a growing number of customers state that they are dissatisfied with their online shopping experiences. However, further research is required to gain a deeper perception of the factors affecting customers' evaluations regarding their online shopping behavior, which subsequently have a bearing on their loyalty (Luo, Ba, \& Zhang, 2012).

The banking industry is no exception to this evolution as the internet has revolutionized industries throughout the world (Hussien \& Aziz, 2013).

Although e-banking, in contrast to traditional banking, enables customers to undertake a wide range of banking activities at any time and place at a low cost (Amin, 2016), the elimination of the role of humans in providing electronic services presents a challenge in gaining customer loyalty (Amin, 2016; Brun, Rajaobelina, \& Ricard, 2014). The staff of a service company can help their enterprise by establishing a close and intimate relationship with customers. In electronic services, customer relationships are established via electronic devices, and online relationship quality can play a central role in customer loyalty (Fong, 2015, Ozen, 2015; Rafiq, Fulford, \& Xiaoming, 2013; Shin, Chunga, Ohb, \& Leec, 2013; Wang, Law, Guillet, \& Hung, 2015).

Relationship quality is deemed to be a general evaluation of a relationship's power and its responsiveness to the needs and expectations of both parties based on successful encounters and events (Smith, 1998). Relationship quality is a multi-dimensional construct composed of several factors that reflect the general nature of the relationship between companies and customers. Despite the lack of a consensus on the dimensions and elements of quality, there is general agreement that satisfaction, trust, and commitment are key elements of relationship quality (Brun et al., 2014; Hennig-Thurau, Gwinner, \& Gremler, 2002; Palmatier, Dant, Grewal, \& Evans, 2006; Smith, 1998; Wang, Liang, \& Wu., 2006). Also, according to Brun et al. (2014), commitment, trust, and satisfaction are constituent elements of relationship quality in the online context.

The current line of research has looked at the relationship between customer relationship quality and customer loyalty, especially in the physical setting (Bilgihan \& Bujisic, 2014; Caceres \& Paparoidami, 2007; Fang, Shao, \& Wen 2016; Hennig-Thurau et al., 2002; Kim, Lee, \& Yoo, 2006; Musa, 2009; Naoui \& Zaiem, 2010; Nusair, Bilgihan, Okumus and Cobanoglu, 2013; Palmatier et al., 2006; Papassapa \& Miller; 2007; Ribbink, van Riel, Liljander, \& Streukens, 2004; Yu \& Tung, 2013). In the online setting, a number of researchers have focused on the link between the quality of the online relationship and customer loyalty (Ozen, 2015; Rafiq et al., 2013; Wang et al., 2015). However, as far as the authors are aware, this is the first article to examine the impact of online relationship quality on customer loyalty over the lifecycle of the relationship.

Most of the previous studies have examined the association between relationship quality and loyalty in a static state. However, according to the theory of dynamic relationship marketing, relationships have a similar lifecycle to products, and as time goes by, the relationship between a firm and its customers changes and enters a new level. At each level of this relationship, different relational constructs are needed to maintain the association (Zhang, Watson IV, Palmatier, \& Dant, 2016a). This reveals that relationships are dynamic and firms therefore need to make different efforts at each stage of the relationship lifecycle to maintain their relationship and gain 
more customer value in the form of loyalty. Thus, academics and business managers need to conduct more empirical research in order to shed further light on the various impacts of relationship quality on customer loyalty during the relationship lifecycle in both online and offline contexts.

The present study, which is based on the relationship dynamics theory (Palmatier et al., 2013), proposes that the association between online relationship quality and customer loyalty varies at different stages of the relationship lifecycle (exploration, buildup, maturity, and decline).

This paper contributes to relationship marketing literature in the following ways. First, it suggests that online relationship quality is a driver of customer loyalty. Second, it implies that the influence of online relationship quality on customer loyalty may vary depending on the different stages of the relationship lifecycle. Third, it provides a real-life analysis of the proposed framework in e-banking services, suggesting that the direction and strength of the link between online relationship quality and customer loyalty change at different stages of the relationship lifecycle.

\section{Theoretical Background}

\section{I Relationship quality}

Relationship quality can be defined as a multi-dimensional construct related to a customer's general assessment of his/her relationship with a service provider at a specific time based on all previous interactions with that provider (Keating, Alpert, Kriz, \& Quazi, 2011). Despite the lack of a consensus regarding the components and dimensions of relationship quality in the literature, a shared line can be identified between various conceptualizations, in that different researchers have proposed satisfaction, commitment, and trust as the key components of relationship quality in the traditional context (Brun et al., 2014; De Wulf, Odekerkenschroder, \& Iacobucci, 2001; Hennig-Thurau et al., 2002; Palmatier et al., 2006; Rafiq et al., 2013; Vesel
\& Zabkar, 2010). Similarly, relationship quality in the online environment has three dimensions, online trust, online satisfaction, and online commitment, which indicate the overall power of the quality of the relationship between online vendors and their customers. In brief, according to the literature, trust, commitment, and satisfaction are among the most important aspects of traditional relationship marketing. Several studies have shown the importance of these three dimensions in online business environments (Brun et al., 2014; Fang et al., 2016).

Previous studies have presented convincing evidence regarding the link between relationship quality, as a higher-level construct consisting of trust, satisfaction, and commitment, and loyalty, as well as the link between each dimension of relationship quality and loyalty (Bilgihan $\&$ Bujisic, 2014; Caceres \& Paparoidamis, 2007; Fang et al., 2016; Hennig- Thurau et al., 2002; Kim et al., 2006; Musa, 2009; Nusair et al., 2013; Naoui \& Zaiem, 2010; Papassapa \& Miller, 2007; Palmatier et al., 2006; Yu \& Tung, 2013;).

In the online context, a number of authors have stressed a conceptualization of relationship quality with independent dimensions, considering it to be made up of components of trust, commitment, and satisfaction (Arcand, Promtep, Brun, \& Rajaobelina, 2017; Brun et al., 2014; Chung \& Shin, 2010; Walsh, HennigThurau, Sassenberg, \& Bornemann, 2010). Thus, in the present study, we have conceptualized online relationship quality using three key dimensions of trust, satisfaction, and commitment as related but independent constructs.

\section{I.I Online trust}

Given the increasing importance of e-commerce, trust in the digital world has received increasing attention from marketing experts and academia (Beldad, Jong, \& Steehouder, 2010). Specifically, online trust is defined as the interplay of positive beliefs or expectations concerning the competency, integrity, and benevolence of a company in an online setting (McKnight et al., 2002).

Many researchers posit that trust is one of the main factors that determine consumers' 
initial and sustained use of e-banking services (Lichtenstein \& Williamson, 2006; Rexha, Kingshott, \& Shang, 2003; Suh \& Han, 2002). However, negative features of online transactions such as a lack of control, risky decision making, a lack of physical contact with online companies, and an absence of tangible capabilities in online exchanges cannot be overlooked (Shin et al., 2013). Therefore, in the context of relationship quality, trust represents one of the prerequisites for success in e-commerce. That is, trust triggers new transactions, while its absence creates a barrier against new transactions. Also, trust is one of the determinants of the online environment as it helps to maintain customers and develop long-term relationships with them (Sahney, Ghosh, \& Shrivastava, 2013). Moreover, it is also an important factor in determining customers' intentions to make online purchases and remain loyal to e-commerce (Pengnate \& Sarathy, 2017).2.1.2 Online commitment

According to Berry and Parasurman (1991), relationships are created based on mutual commitment. Morgan and Hunt (1994) view commitment as being at the heart of successful long-term relationships. Given that commitment is a basic variable in measuring the future of seller-purchaser relationships, most studies on relationship marketing have treated it as an important dimension of relationship quality (Brun et al., 2014; Cambra-Fierro, MeleroPolo, \& Javier 2018; De Wulf et al., 2001; De Wulf et al., 2003; Hennig-Thurau et al., 2002; Palmatier, 2006; Roberts, Varki, \& Brodie 2003; See Dorsch, 1998; Wang et al., 2006). Berry and Parasurman (1991) define commitment as a vital part of a successful relationship that can foster loyalty. In general, studies on relationship marketing tend to treat commitment in terms of emotional commitment. Such commitment is usually assumed to be an attitudinal construct (Bansal, Irving, \& Taylor, 2004; Fullerton, 2003; Gundlach, Achrol, \& Mentzer 1995).

In the online environment, commitment refers to a type of relationship and tendency that is comparable to emotional commitment. Online commitment is defined as the consumer's desire to continue communication with an online vendor (Rafiq et al., 2013).

\section{I.3 Online satisfaction}

As another dimension of relationship quality, customer satisfaction plays an important role in competitive environments due to its impact on loyalty (Brun et al., 2014). Online customer satisfaction represents the level at which customers assess their online purchases in general (Al-Hawari, 2014). Internet users often rely on the quality of online systems and the information provided on the website when assessing their online shopping experiences to compensate for the lack of physical contact in traditional transactions. Thus, in online purchases, consumer satisfaction is often associated with the website and its quality rather than the actual items on sale (Brun et al., 2014).

\subsection{Online loyalty}

Loyalty plays a pivotal role in the survival and development of e-commerce (Chen, 2012) as it is a major driver of continued contact with the organization (Rafiq et al., 2013). Online loyalty can be described as a desirable customer attitude and commitment to online shopping, which convinces the customer to repeat his/her shopping behavior (Toufaily \& Pons, 2017). Online loyalty of customers to a bank indicates their intention to revisit the bank's website and consider reusing a given product and service in the future (Amin, 2016). Therefore, it can be said that retaining current customers and strengthening their loyalty are main tasks of service providers seeking to gain a competitive advantage (Chen \& Wang, 2016), as obtaining loyal customers on the internet can be a serious challenge (Chang $\&$ Wang, 2011).

E-loyalty is a concept that has been extensively discussed in online banking literature (e.g. Mohsin \& Aftab, 2013; Al-Hawari, 2014). It is important to focus on online customer loyalty to online banking in order to maintain relationships with customers. In this context, 
highly loyal customers tend to visit a website frequently and suggest that site to others (Amin, Isa, \& Fontaine 2013).2.3 Relationship lifecycle

The existing models of the relationship development process reveal that marketing relationships are inherently dynamic. These models are derived from the interpersonal relationship literature and demonstrate differences in the various stages of the relationship lifecycle (Hansen, Beitelspacher, \& Deit, 2013). Many studies that assume relationships involve a dynamic process are inspired by the study from Dwyer, Schurr, and Oh (1987).

Chris and Karen (2005) assessed the customer relationship lifecycle based on the time and intensity of the relationship. This lifecycle represents the evolution of relationships over time along with their intensity at each stage. According to Dwyer et al. (1987), lifecycle generally covers five stages of evolution: awareness, exploration, development, commitment, and dissolution. Jap and Ganesan (2000) also specify five stages in the evolution of a lifecycle: awareness, exploration, buildup, maturity, and decline. Despite the different titles used for the various stages, there is a general consensus that the level of each relationship aspect varies from one stage to another.

Since this study looks into the relationship between a bank and its existing customers, the awareness stage has been eliminated as the bankcustomer relationship is yet to be established at that stage. Accordingly, as suggested by Jap and Ganesan (2000), the stages of exploration, buildup, maturity, and decline of the relationship have been considered as the four phases of the relationship in this paper.

\section{Hypothesis Development}

\section{I Online trust and online loyalty}

Reichheld and Phil (2000) contend that to gain the customer's loyalty, it is necessary to obtain their trust. Lau and Lee (1999) found a significant positive correlation between customer trust in a certain brand and their loyalty to that brand. Likewise, Chaudhuri and Holbrook (2001) discovered a significant relationship between trust in a brand and customers' attitudinal and behavioral loyalty.

Furthermore, the studies by Wang et al. (2015), Polites, Williams, Karahanna, and Seligman (2012), Ribbink et al. (2004), Safa and Ismail (2013), and Shin et al. (2013) demonstrate the impact of trust on loyalty. Therefore, the first hypothesis of this research is presented as follows:

H1: Online trust has a positive effect on loyalty in e-banking services.

\subsection{Online commitment and online loyalty}

Commitment is a key term for researchers and marketers who study online and web-based environments (Park \& Kim, 2003; Ozen, 2015), online retailing (Rafiq et al. 2013), internet shopping (Chung \& Shin, 2010), e-banking (Mukherjee \& Nath, 2007; Sanchez-Franco, 2009; Keating et al, 2011 ), and banking (Rahman \& Ramli, 2016). Most of these studies have focused on the association between commitment, satisfaction, trust, loyalty, and intention to purchase/repurchase, among other things. In the marketing research, commitment is a major variable that distinguishes between loyal and nonloyal customers. That is, commitment signifies the tendency to continue a relationship and ensures its sustainability (Rafiq et al, 2013). Based on the above, the second hypothesis is formulated:

H2: Online commitment has a positive impact on loyalty to e-banking services.

\subsection{Online satisfaction and online loyalty}

Bitner (1990) argues that satisfaction is an antecedent to loyalty. Also, Oliva, Oliver, and MacMillan (1992) have shown that satisfaction and loyalty are significantly correlated. 
While the positive relationship between e-satisfaction and e-loyalty has been explored extensively in the e-commerce retailing literature (Anderson \& Srinivasan, 2003; Chandrashekaran, Rotte, Tax, \& Grewal, 2007; Chang, Wang, \& Yang, 2009; Cyr, 2008; Flavián, Guinalíu, \& Gurrea, 2006; Gummerus, Liljander, Pura, \& van Riel, 2004; Harris \& Goode, 2004; Jin \& Park, 2006; Luarn \& Lin, 2003; Yang \& Peterson, 2004), the relationship between e-satisfaction and e-loyalty in the e-banking context is at a relatively nascent stage, with few studies examining the impact of e-satisfaction on e-loyalty in e-banking (Ariño, Flavián, \& Guinalíu, 2008; Aldas-Manzano, Ruiz-Mafe, Sanz-Blas, \& Lassala-Navarré, 2011; Al-Hawari, 2014; Amin, 2016; Levy, 2014; Mohsin \& Aftab, 2013; Sampaio, Ladeira, \& Santini, 2017). Thus, the following hypothesis is presented to consider online satisfaction:

H3: Online satisfaction has a positive impact on loyalty in e-banking services.

\subsection{Moderating effect of the relationship lifecycle on the quality-loyalty link}

Previous studies have explored the effect of relationship quality on customer loyalty from a static perspective. Also, in a number of studies that have examined this relationship from a dynamic perspective by introducing the relationship lifecycle variable, this dynamism has been confined to a mere analysis of the status of trust and commitment at different stages of the relationship lifecycle, with few examining the relationship lifecycle as a moderating variable in the interplay between relationship quality and customer loyalty. For instance, Jap and Anderson (2007) investigated the role of trust in four stages of the relationship lifecycle (exploration, buildup, maturity, and decline), concluding that the highest trust in the producer was observed in the buildup, then the maturity, and then the exploration stages, and the lowest trust was observed in the decline stage. Furthermore, Palmatier et al. (2013) demonstrated that commitment improves until the fourth year of the relationship but tends to decrease between the fourth and the sixth years.

Some of the relationship constructs (e.g. trust, coherence norms, and commitment) develop over a longer period of time while others grow at faster rates. For this reason, different constructs of the relationship may become dominant at different stages of it (Dwyer et al., 1987). For example, trust may be highly active at the early stages of a relationship as the buyer and seller are less likely to build a long-term relationship unless they are able to assess the extent to which they trust each other. However, trust may become inactive (latent) in the following stages and not receive the same level of management attention (Wilson, 1995). Nonetheless, this does not diminish the importance of trust in the later stages.

The scant empirical studies in both areas of marketing, i.e., industrial and consumer marketing, show that the association between relationship quality dimensions and customer performance outcomes such as loyalty changes at different levels of the relationship, but the mechanism of this change is not the same. For instance, Hibbard, Jonathan, Frederic, Rajiv, and Iacobucci (2001) argue that as the relationship ages, the importance of commitment in predicting relationship performance declines, but the role of trust in predicting relationship performance increases, until the third and fourth stages of the relationship, when it declines again. However, Zhang et al. (2016a) showed that trust and commitment are strengthened along with customer performance up to the third stage of the relationship lifecycle, but drop in the fourth stage (relationship decline). Also, the findings of Verhoef, Franses, and Hoekstra (2002) suggest that the age of the relationship increases the positive effect of satisfaction and commitment on the number of services purchased. CambraFierro et al. (2018) showed that in the buildup and maturity stages, the impact of relationship quality on customer value co-creation was stronger than in the decline stage. 
The different results suggest that further research is required to understand the mechanism by which the relationship quality dimensions affect relationship performance, especially customer loyalty. Therefore, the following hypotheses are put forward:

H4: The impact of online trust on customer loyalty varies at different stages of the relationship lifecycle.
H5: The impact of online commitment on customer loyalty varies at different stages of the relationship lifecycle.

H6: The impact of online satisfaction on customer loyalty varies at different stages of the relationship lifecycle.

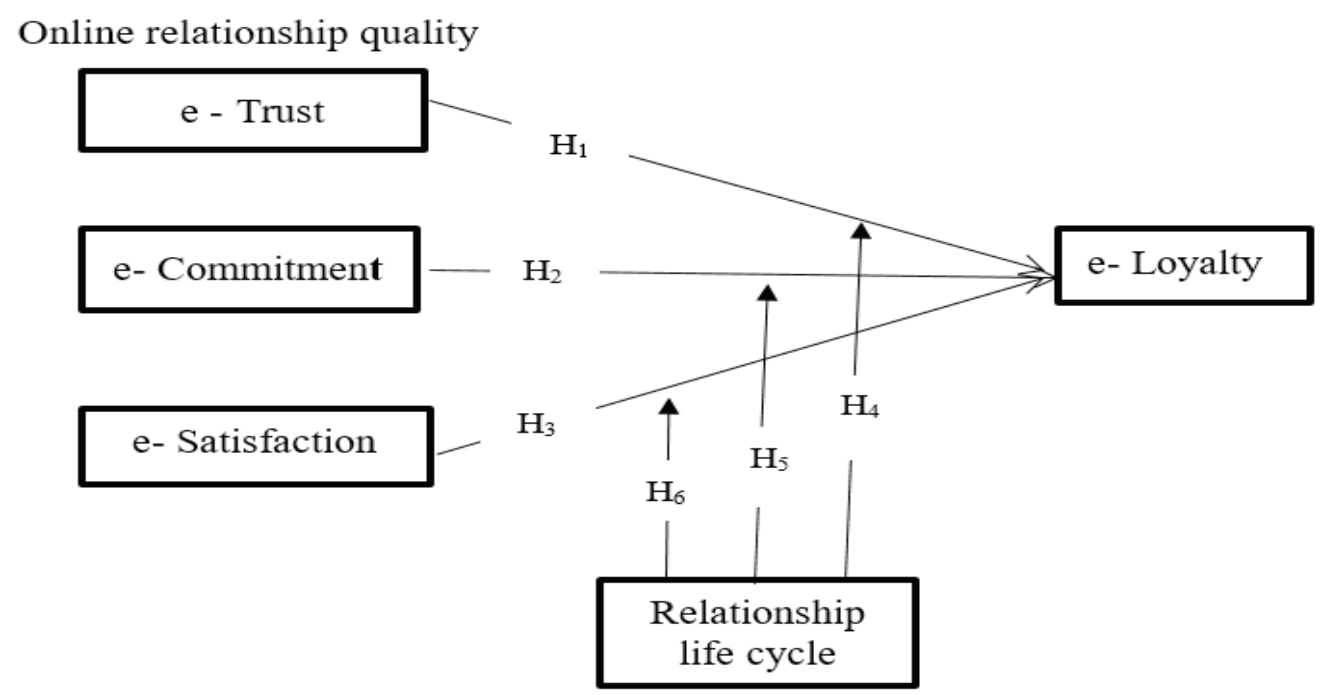

Figure 1. The conceptual model of the research

\section{Method}

A standardized self-administered questionnaire was developed based on an extensive literature review. The variables used in this research were adapted from previous studies. The research variables include online relationship quality, customer loyalty, and relationship lifecycle (as the moderator). Online relationship quality was conceptualized based on three dimensions: trust, commitment, and satisfaction. Online trust was measured using six items suggested by Fang et al. (2016), Toufaily and Pons (2017), Brun et al. (2014), and Shin et al. (2013). Online commitment was assessed based on the studies of Fang et al. (2016), Brun et al. (2014), Shin et al. (2013), and Cater and Zabkar (2009), using four items. Online satisfaction was also measured by three items suggested by Fang et al. (2016) and Wang, Wang, and Liu (2016). Electronic customer loyalty was evaluated by six items derived from the studies of Alonso-Almeida, Bernardo, Llach and Marimon (2014), Amin (2016), Bernardo, Marimon, and Alonso-Almeida (2012), and Toufaily and Pons (2017). Finally, the relationship lifecycle was measured by a fourpoint scale proposed by Jap and Ganesan (2000).

A total of 19 items were used to measure the constructs in this model. Of these items, four were removed at the assessment stage as their factor loadings were below the acceptable level 
(three items related to online commitment and one related to online loyalty), and so 15 items were included in the final model.

Table 2 displays the measurement items and research constructs along with their sources. All of the measurement scales reflected the underlying constructs, for which a 7-point Likert scale was used (ranging from "strongly disagree" to "strongly agree"). The relationship lifecycle was measured by four choice items on a nominal scale, with each choice representing a stage of the relationship lifecycle (i.e. exploration, buildup, maturity, and decline).

The respondents were asked to specify the level of their relationship with the bank by choosing one of the options. In previous studies, besides the relationship lifecycle, other parameters such as the age or length of the relationship have been used to measure the relationship stage. However, as indicated in the literature, the relationship lifecycle is the most effective method to determine the level or stage of the relationship (Jap \& Ganesan, 2000). The relationship lifecycle suggests that relationship formation is an evolutionary process while the relationship age approach overlooks temporal variations by assuming that all relationships in the lifecycle move at an equal rate (Palmatier et al., 2013). Thus, age is not a suitable criterion to measure the stages of the relationship. Some relationships may reach the stage of maturity, whereas others might still remain in the stage of development even after several years (Eggert et al., 2006).

The final draft of the questionnaire was prepared after a thorough review of the related literature. Bank managers' views were taken into account and we conducted interviews with a number of bank customers. In the final step, the opinions of marketing experts were sought. The goal of this step was to assess the measures adopted in the study. The first draft of the questionnaire was constantly modified throughout these steps. The revised version was sent via email to 750 customers of Iranian banks in East Azerbaijan Province who had used e-bank services, 651 of whom agreed to fill out the questionnaire. This yielded a response rate of $86 \%$, which was adequate for structural equation modeling (SEM). In terms of gender, $51.9 \%$ of the respondents were female and $37.8 \%$ were in the age range of 21 to 30 years. (See Table 1 for the participants' demographic information).

Table 1

\section{Demographic Data}

\begin{tabular}{|c|c|c|c|}
\hline & & $\begin{array}{l}\text { Number of } \\
\text { Respondents }\end{array}$ & $\%$ \\
\hline \multirow{2}{*}{ Gender } & Male & 338 & 51.9 \\
\hline & Female & 313 & 48.1 \\
\hline \multirow{6}{*}{ Age } & Less than 20 & 37 & 5.7 \\
\hline & $21-30$ & 246 & 37.8 \\
\hline & $31-40$ & 221 & 33.9 \\
\hline & $41-50$ & 99 & 15.2 \\
\hline & $51-60$ & 34 & 5.2 \\
\hline & $61+$ & 14 & 2.2 \\
\hline \multirow{5}{*}{$\begin{array}{l}\text { Education } \\
\text { background }\end{array}$} & $\begin{array}{l}\text { High school } \\
\text { diploma }\end{array}$ & 37 & 5.7 \\
\hline & Diploma & 122 & 18.7 \\
\hline & Associate Degree & 122 & 18.7 \\
\hline & Bachelor & 213 & 32.7 \\
\hline & $\begin{array}{l}\text { Master's and } \\
\text { Doctorate }\end{array}$ & 157 & 24.1 \\
\hline
\end{tabular}

\section{Analysis Approach}

The data analysis was performed by SEM in the Amos 23 software using a 2-step approach (Anderson \& Gerbing, 1988). Delineating the patterns of relationships between constructs was the primary focus of the study; therefore, a correlation matrix was used to estimate the structural model (Hair, Black, Babin, Anderson, \& Tatham, 1995). Cronbach's alpha was utilized to evaluate the internal consistency of the scales. With an alpha value greater than 0.70 , all measurements confirmed the reliability of the model.

$$
\text { Confirmatory factor analysis (CFA) }
$$
was used to determine whether the number of factors and loadings of the measured items were consistent with expectations, based on previous 
research and the theory. Also, CFA was performed to assess the overall validity of the measurement model. The final measurement model indicated a good fit of the 15-item model with $\chi 2=243.946$; $d f=84 ; \mathrm{p}<0.001 ; \mathrm{CFI}=0.973$; RMSEA = 0.054; $\mathrm{NFI}=0.959$; and TLI $=0.966$. Additionally, the results confirmed the construct validity of the measurement model.

The internal consistency, validity, and reliability of the scales were further examined using three indicators: composite reliability (CR), Cronbach's alpha $(\alpha)$, and average variance extracted (AVE). The acceptable values for CR, AVE, and Cronbach's alpha are above 0.5 (Anderson \& Gerbing, 1988), 0.7 (Fornell \& Larcker, 1981), and 0.7 (Nunnally \& Bernstein, 1994), respectively. As shown in Table 2, CR, AVE, and Cronbach's alpha values were calculated for each construct, with the results indicating that all constructs are within the acceptable range. Therefore, it can be stated that the constructs had acceptable reliability.
Moreover, to assess validity, the square root of the AVE was compared to all inter-factor correlation coefficients. As shown in Table 3, the least squares were computed by comparing correlations between each pair of constructs and the square root of the corresponding AVE values of all constructs (Fornell \& Larcker, 1981).

The factor loadings and fitness of the indices are presented in Table 2. To improve the model fitness and obtain a factor loading of greater than 0.5 , four items were removed, leaving a 15item questionnaire. Although the loading factor of item 7 was $0.42(<0.5)$, the effect of this item on lowering the value was more than the other model indicators. Thus, as suggested by Tabachink and Fidel (1996), who consider factor loadings greater than 0.32 as acceptable, this item was retained in the questionnaire (Meyers, Gamest, \& Goarin, 2006). 
Table 2

\section{List of items and their sources with reliability and dimensionality indicators}

\begin{tabular}{|c|c|c|c|c|}
\hline Constructs and items and their sources & $\begin{array}{l}\text { Factor } \\
\text { loadings }\end{array}$ & $\begin{array}{l}\text { Cronbach's } \\
\text { alpha }(\alpha)\end{array}$ & CR & AVE \\
\hline \multicolumn{5}{|l|}{ Online Relationship Quality } \\
\hline \multicolumn{2}{|c|}{ e-Trust (Brun et al., 2014; Fang et al., 2016; Shin et al., 2013; Toufaily \& Pons, 2017) } & 0.839 & 0.841 & 0.638 \\
\hline $\begin{array}{l}\text { I trust the information that is provided in the online environment of this } \\
\text { bank }\end{array}$ & .78 & & & \\
\hline I trust the promises that the bank makes in the online environment & .85 & & & \\
\hline I trust the e-services that the bank provides & .77 & & & \\
\hline \multicolumn{2}{|c|}{ e-Commitment (Brun et al., 2014; Cater \& Zabkar, 2009; Fang et al., 2016; Shin et al., 2013) } & 0.753 & 0.844 & 0.590 \\
\hline I feel the e-services of this bank are a part of my life & 420 & & & \\
\hline I am dependent on the e-services of this bank to do my banking tasks & .84 & & & \\
\hline Stopping using the e-services of this bank would be too difficult for me & .90 & & & \\
\hline $\begin{array}{l}\text { If I decided to stop using the e-services of this bank then managing my } \\
\text { financial tasks would be difficult }\end{array}$ & .82 & & & \\
\hline \multicolumn{2}{|l|}{ e-Satisfaction (Fang et al., 2016; Wang et al., 2016) } & 0.854 & 0.859 & 0.671 \\
\hline I am satisfied doing my banking tasks through the e-services of this bank & .76 & & & \\
\hline The e-services of this bank have fulfilled my expectations & .88 & & & \\
\hline I am satisfied with my decision to use the e-services of this bank & .82 & & & \\
\hline \multicolumn{2}{|c|}{$\begin{array}{l}\text { e-Loyalty (Alonso-Almeida et al., 2014; Amin, 2016; Bernardo et al., 2012; Toufaily \& Pons, } \\
\text { 2017) }\end{array}$} & 0.895 & 0.896 & 0.633 \\
\hline I mention the positive options of the e-services of this bank to other people & .70 & & & \\
\hline I prefer using the e-services of this bank to those of other banks & .77 & & & \\
\hline I intend to use the e-services of this bank in the future & .80 & & & \\
\hline I doubt I'll change bank as long this one continues to provide its e-services & .86 & & & \\
\hline When I need banking services the e-services of this bank are my first choices & .84 & & & \\
\hline
\end{tabular}

The square roots of the AVE for the different constructs are displayed on the diagonal line in Table 3. As shown in the table, the values of the square roots of the AVE for all constructs were greater than the inter-construct correlations (Fornell \& Larcker, 1981), which verified the discriminant validity. Hence, the good construct validity of the measurement model is confirmed.

Table 3

\section{Correlation matrix and square roots of AVEs}

\begin{tabular}{lcccc}
\hline Construct & Commitment & Loyalty & Satisfaction & Trust \\
\hline Commitment & 0.768 & & & \\
Loyalty & 0.757 & 0.795 & $\mathbf{0 . 8 1 9}$ & 0.565 \\
Satisfaction & 0.589 & 0.677 & 0.799 \\
Trust & 0.539 & 0.645 & 0.59 \\
\hline
\end{tabular}

Note. The numbers on the diagonal are the square root of the AVE. 


\section{Results}

\section{I Evaluation of the structural model}

Table 4 and Figure 2 illustrate the hypothesized relationships along with a summary of the hypotheses supported by the results. Table 4 shows that all three aspects of online relationship quality (online trust, satisfaction, and commitment) have a positive effect on customer loyalty to the e-banking services. The goodnessof-fit indices showed the adequate fitness of the model, though a significant chi-square was obtained $\left(\chi^{2}=243.946, \mathrm{df}=84, \mathrm{P}<0.001, \mathrm{~N}\right.$ $=651)$. Given that the likelihood ratio based on the chi-square is sensitive to the sample size (Byrne, 2001), a relative chi-square statistic $\left(\chi^{2} /\right.$ df) is often used as a goodness-of-fit measure. The estimated value of $\chi^{2} / \mathrm{df}$ in this study was 2.904 , which is lower than the threshold limit of 5 (Hair et al., 1998). The GFI, AGFI, NFI, CFI, TLI, and RSMEA were 0.952, 0.931, 0.959, 0.973, 0.966, and 0.054 , respectively.

Table 4

Testing the research hypotheses using standardized estimates

\begin{tabular}{llcccccc}
\hline Hypothesis & \multicolumn{1}{c}{ Hypothesized Path } & $\begin{array}{c}\text { UnStd. } \\
\text { estimate }\end{array}$ & S.E & $\begin{array}{c}\text { Std. } \\
\text { estimate }\end{array}$ & t-value & p & Supported \\
\hline H1 & Trust $\rightarrow$ Lealdade & 231,0 & 039,0 & 243,0 & 5,868 & 0,000 & YES \\
H2 & Commitment $\rightarrow$ Loyalty & 347,0 & 044,0 & 472,0 & 7,856 & 0,000 & YES \\
H3 & Satisfaction $\rightarrow$ Loyalty & 250,0 & 041,0 & 262,0 & 6,070 & 0,000 & YES \\
\hline
\end{tabular}

The results indicated that all three paths were significant at $\mathrm{p}<0.001$ in the structural model. The results of the structural model test revealed the positive contributions of online commitment $(\mathrm{SE}=0.472, \mathrm{p}<0.001)$, online satisfaction $(\mathrm{SE}=0.262, \mathrm{p}<0.001)$, and online trust $(\mathrm{SE}=0.243, \mathrm{p}<0.001)$ to e-loyalty.

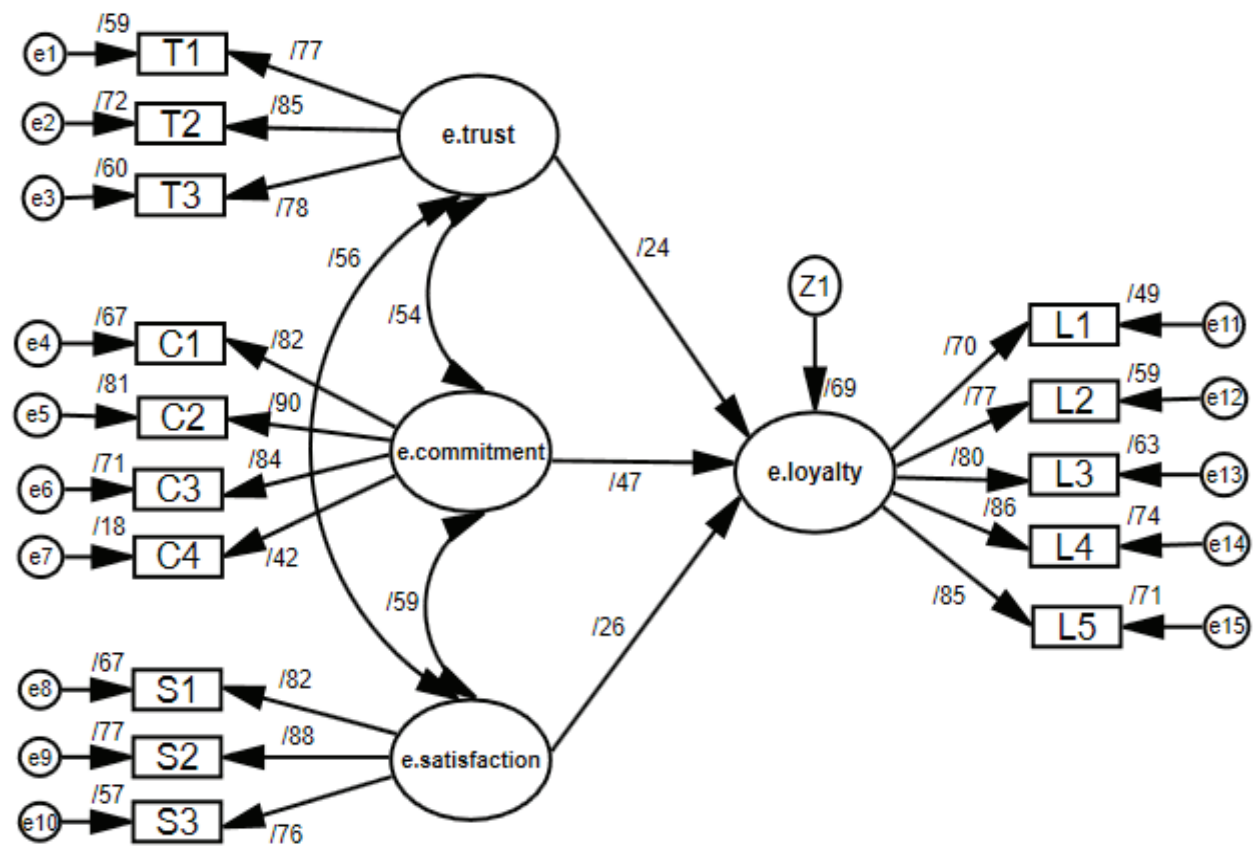

Figure 2. Results of the hypothesized structural model 


\subsection{Evaluation of lifecycle moderator model}

To test the effect of the moderator variable on the relationship lifecycle, multi-group SEM was used and the results are presented in Tables 5 and 6 .

Table 5

Estimation of path coefficients at different stages of the relationship lifecycle

\begin{tabular}{|c|c|c|c|c|c|c|c|c|c|c|c|c|c|}
\hline \multirow{2}{*}{ 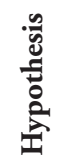 } & \multirow[b]{2}{*}{ Assumed path } & \multicolumn{3}{|c|}{ Exploration stage } & \multicolumn{3}{|c|}{ Buildup stage } & \multicolumn{3}{|c|}{ Maturity stage } & \multicolumn{3}{|c|}{ Decline stage } \\
\hline & & $\beta$ & t-value & $\mathbf{P}$ & $\beta$ & t-value & $\mathbf{P}$ & $\beta$ & t-value & $\mathbf{P}$ & $\beta$ & t-value & $\mathbf{P}$ \\
\hline $\mathrm{H} 4$ & $\begin{array}{l}\text { Trust } \\
\rightarrow \text { Lealdade }\end{array}$ & 0,179 & 10,745 & 0,061 & 0,258 & 20,707 & 0,007 & 0,485 & 40,773 & 0,000 & 0,159 & 10,022 & 0,307 \\
\hline H5 & $\begin{array}{l}\text { Commitment } \\
\rightarrow \text { Loyalty }\end{array}$ & 0,628 & 40,305 & 0,000 & 0,343 & 30,765 & 0,000 & 0,258 & 30,188 & 0,001 & 0,041 & 0,272 & 0,785 \\
\hline H6 & $\begin{array}{l}\text { Satisfaction } \\
\rightarrow \text { Loyalty }\end{array}$ & 0,118 & 10,130 & 0,259 & 0,277 & 30,052 & 0,002 & 0,248 & 20,963 & 0,003 & 0,266 & 10,590 & 0,112 \\
\hline
\end{tabular}

The results of Table 5 reveal that the effect of online trust on customer loyalty is significant at a $99 \%$ confidence interval in the buildup and maturity stages and at a $90 \%$ confidence interval in the exploration stage, but it did not have any significant effect on customer online loyalty in the decline stage $(\mathbb{Q}=0.159 ; \mathrm{p}>0.1)$. Considering the significance of the changes in $\bigotimes 2$ in Table $6(\Delta \bigotimes 2=$ 6.614; $\mathrm{p}<0.1$ ), Hypothesis 4 is confirmed, i.e. the effect of online trust on customer loyalty differs at various stages of the relationship lifecycle.

The analysis of the beta coefficients obtained in the four stages showed that online trust has the greatest effect on customer loyalty in the maturity $(\mathbb{Q}=0.485)$, buildup $(\mathbb{Q}=0.258)$, and exploration $(\bigotimes=0.179)$ stages, respectively. More precisely, as the relationship ages, the impact of online trust on customer loyalty rises, but as the relationship reaches the decline stage, the impact of online trust on loyalty drops to a minimum.

According to the results of the analysis, in the exploration, buildup, and maturity stages, the effect of online commitment on customer loyalty is significant at a $99 \%$ confidence interval.
However, in the decline stage, online commitment does not have any effect on customer loyalty ( $\square$ $=0.041 ; \mathrm{p}>0.1$ ).

Considering the significance of the changes in $\triangle 2$ in Table $6(\Delta \bigotimes 2=8.901 ; \mathrm{p}<0.05)$, Hypothesis 5 is confirmed, meaning that the effect of online commitment on customer loyalty differs at various stages of the relationship lifecycle.

In addition, using the estimated $\otimes$ coefficients, the differences between the four subsamples can be detected. The values of the exploration stage are higher, followed by those of the buildup and maturity stages, respectively. In other words, with increased duration of the relationship, the impact of online commitment on customer loyalty declines.

With regard to Hypothesis 6, it can be concluded that although online satisfaction had a significant effect on customer loyalty in the buildup and maturity stages, considering that the changes in $\mathrm{X}^{2}$ in Table $6\left(\Delta \mathrm{X}^{2}=6.614 ; \mathrm{p}<0.1\right)$ are not significant, Hypothesis 6 is rejected. That is, the effect of online satisfaction on customer loyalty is similar at different stages of the lifecycle. 
Table 6

Comparison of $\chi^{2}$ value differences (testing consistency of path coefficients) in different stages of the relationship lifecycle

\begin{tabular}{llccccc}
\hline Hypothesis & Assumed path & Model & $\chi^{2}$ & df & $\boldsymbol{\Delta}_{\mathbf{X} 2}$ & $\mathbf{p}$ \\
\hline \multirow{2}{*}{ H4 } & \multirow{2}{*}{ Trust $\rightarrow$ Lealdade } & Unrestricted model & 625,193 & 336 & - & - \\
& & Equal mode & 631,807 & 339 & 6,614 & 0,085 \\
\multirow{2}{*}{ H5 } & \multirow{2}{*}{ Commitment $\rightarrow$ Loyalty } & Unrestricted model & 625,193 & 336 & - & - \\
& & Equal model & 634,093 & 339 & 8,901 &, 0310 \\
H6 & \multirow{2}{*}{ Satisfaction $\rightarrow$ Loyalty } & Unrestricted model & 625,193 & 336 & - & - \\
& & Equal mode & 629,031 & 339 & 3,839 &, 2790 \\
\hline
\end{tabular}

\section{Discussion and Managerial Implications}

The main goal of this paper was to investigate the link between relationship quality and customer loyalty at different stages of the relationship lifecycle in the e-banking context. The increasing use of the internet in businesses and the development of a highly competitive and challenging environment in various industries, including the banking industry, along with the problems inherent to this kind of business, including a lack of physical contact with online companies, a lack of touch capabilities in online exchanges, and an absence of control and decisionmaking in online commerce, have driven online companies to seek a competitive advantage and establish loyalty and long-term relationships with customers. Hence, in addition to focusing on the quality of services, they pay greater attention to the quality of their relationships with customers in a bid to establish relationships based on trust and mutual commitment and to attain customer satisfaction. A number of conclusions can be drawn from the findings of this study.

The results of testing the hypotheses showed that online satisfaction, commitment, and trust have positive effects on online loyalty. These results are consistent with those reported in previous studies (Amin, 2016; Giovanis et al., 2015; Levy, 2014; Rahman \& Ramli, 2016; Sharifi \& Esfidani, 2014; Wang et al., 2015). In other words, increased customer commitment, satisfaction, and trust lead to greater loyalty to online banking in the long run. However, a meticulous analysis of the results indicates that the effect of satisfaction on loyalty is greater than that of commitment and trust. Thus, banks should develop strategies to improve the quality of online relationships to further enhance online loyalty. In this regard, managers are advised to build confidence by fulfilling promises made by the bank in the online environment, to foster trust in the information and services provided, to implement accurate banking transactions, to reinforce customer commitment to online services by offering comprehensive and convenient services, and to meet customers' expectations in order to nurture their loyalty to the online services.

A variety of results were obtained from the different stages of the relationship lifecycle. The effect of online trust on loyalty was not significant in the exploration stage of the relationship, but it increased in the later stages as further communication was established and a larger number of customers used the online services. As such, the effect of trust in the maturity and buildup stages of the relationship was higher than in the exploratory stage.

In other words, customer trust in online services grows with the development of the relationship lifecycle. Finally, in the decline stage of the relationship, the impact of trust on loyalty falls to its lowest level. These finding are consistent with the results reported by Dwyer et al. (1987), Hibbard et al. (2001), and Zhang, Li, Wang, and Wang, (2016b). 
However, regarding the impact of online commitment on online loyalty, the results indicated that as customers move further along the relationship lifecycle, the impact of online commitment on customer loyalty diminishes. Although it may appear to go against common sense, this finding is consistent with some empirical studies in this field. According to Hibbard et al. (2001), as relationships age, the importance of relationship quality variables in predicting customer performance declines. Moorman et al. (1992) argue that relationshipbased partnerships become obsolete over time, and therefore the neutrality of the relationship is reduced. With both sides' expectations and opportunism rising, the continuation of the relationship is threatened.

Therefore, in addition to improving online relationship quality by strengthening online loyalty in customers, banks have to consider other options too. According to our results, the amount of trust in early stages of the relationship is trivial, but it grows over time as the relationship develops, so banks need to pay greater attention to customers in the first and second stages (exploration and buildup) to drive customers into the maturity stage of the relationship. For customers who are in the maturity phase, banks should try to maintain trust and enhance customer loyalty by providing services that are more attractive than those offered by competitors. Nonetheless, given the diminishing effect of commitment on loyalty at later stages, banks need to look for other solutions to ensure loyalty in the long run (e.g. through appreciation or the provision of customized services to customers along with the current basic services), in a bid to draw their attention and ensure their loyalty in the long term. Banks should also identify important customers during the relationship lifecycle and formulate appropriate marketing strategies in fitting with various groups of customers to maintain and develop their relationship.

\section{Limitations and Further Research}

This research had a number of limitations. First, the dynamics of the relationship were assessed by adding the lifecycle variable to the model. This was undertaken despite the fact that our study was cross-sectional and the research data were collected during a specific time interval. Accordingly, further insights into the dynamics of the relationship and possibly different outcomes could be obtained in a longitudinal study. Therefore, interested researchers are advised to collect and analyze data over several years. Second, the results of the present research are exclusive to the financial services sector, so caution must be practiced in generalizing and applying them to other services and industries. To ensure the generalizability of the results, researchers need to implement this study empirically in other services in future research. Finally, to develop a new avenue of research, researchers are advised to examine the mediating effect of other variables, such as customer involvement.

\section{References}

Aldas-Manzano, J., Ruiz-Mafe, C., Sanz-Blas, S., \& Lassala-Navarré, C. (2011). Internet banking loyalty: Evaluating the role of trust, satisfaction, perceived risk and frequency of use, The Service Industries Journal, 31(7), 1165-1190.

Al-Hawari, M. (2014). Does customer sociability matter? Differences in e-quality, e-satisfaction, and e-loyalty between introvert and extravert online banking users. Journal of Services Marketing, 28 (7), 538 - 546. http://dx.doi.org/10.1108/JSM02-2013-0036.

Alonso-Almeida, M. D. M., Bernardo, M., Llach, J., \& Marimon, F. (2014). Building loyalty through functional and hedonic quality. Industrial Management \& Data Systems, 114(3), 387-404. http://dx.doi.org/10.1108/IMDS-062013-0278.

Amin, M. (2016). Internet banking service quality and its implication on e-customer satisfaction and e-customer loyalty. International Journal of Bank Marketing, 34(3), 280-306. http://dx.doi. org/10.1108/IJBM-10-2014-0139. 
Amin, M., Isa, Z., \& Fontaine, R. (2013). Islamic banks: Contrasting the drivers of customer satisfaction on image, trust, and loyalty of Muslim and non-Muslim customers in Malaysia. International Journal of Bank Marketing, 31(2), 79-97, http://dx.doi. org/10.1108/02652321311298627.

Anderson, J. C., \& Gerbing, D. W. (1988). Structural equation modeling in practice: A review and recommended two-step approach. Psychological Bulletin, 103(3), 411-423.

Anderson, R. E., \& Srinivasan, S. S. (2003). E-satisfaction and e-loyalty: a contingency framework. Psychology \& Marketing, 20(2), 123138, DOI: 10.1002/mar.10063.

Arcand, M., Promtep, S., Brun, I., \& Rajaobelina, L. (2017). Mobile banking service quality and customer relationships. International Journal of Bank Marketing, 35(7), 1068-1089. DOI: 10.1108/IJBM-10-2015-0150.

Bansal, H., Irving, G., \& Taylor, S. (2004). A three-component model of customer commitment to service providers. Journal of Academy of Marketing Science, 32(3), 234-250. DOI: $10.1177 / 0092070304263332$

Beldad, A. Jong, M.d., \& Steehouder, M. (2010). How shall I trust the faceless and the intangible? A literature review on the antecedents of online trust. Computers in Human Behavior, 26(5), 857-869

Bernardo, M., Marimon, F., \& Alonso-Almeida, M. D. M. (2012). Functional quality and hedonic quality: A study of the dimensions of e-service quality in online travel agencies, Information \& Management, 49(7-8), 342-347. http://dx.doi. org/10.1016/j.im.2012.06.005.

Berry, L. L., \& Parasuraman, A. (1991). Marketing services: Competing through quality. New York: The Free Press.
Bilgihan, A., \& Bujisic, M. (2014). The effect of website features in online relationship marketing: A case of online hotel booking. Electronic Commerce Research and Applications, 14(4), 222-232. http:// dx.doi.org/10.1016/j.elerap.2014.09.001.

Bitner, M. J. (1990). Evaluating service encounters: The effect of physical surroundings and employee responses. Journal of Marketing, 54(2), 69-82.

Brun, I., Rajaobelina, L., \& Ricard, L. (2014). Online relationship quality: Scale development and initial testing. International. Journal of Bank Marketing, 32(1), 5-27. http://dx.doi.org/10.1108/IJBM-02-2013-0022.

Caceres, I., \& Paparoidamis V. (2007). Service quality, relationship satisfaction, trust, commitment and business to business loyalty. European journal of Marketing, 41(7-8), 836-867. https://doi. org/10.1108/03090560710752429

Cambra-Fierro, J., Melero-Polo, I., \& Javier S. F. (2018). Customer value co-creation over the relationship life cycle. Journal of Service Theory and Practice, 28(3), 336-355. https://doi. org/10.1108/ JSTP-01-2017-0009.

Ariño, L.V., Flavián, C., \& Guinalíu, M. (2008). The role of satisfaction and website usability in developing customer loyalty and positive wordof-mouth in the e-banking services. International Journal of Bank Marketing, 26(6), 399-417. http:// dx.doi.org/10.1108/02652320810902433.

Cater, B., \& Zabkar, V. (2009). Antecedents and consequences of commitment in marketing research services: The client's perspective. Industrial Marketing Management, 38 (7), 785-797. http:// doi.org/10.1016/j.indmarman.2007.10.004.

Chandrashekaran, M., Rotte, K., Tax, S. S., \& Grewal, R. (2007). Satisfaction strength and customer loyalty. Journal of Marketing Research, 44 (1), 153-163.

Chang, H, H., \& Wang, H.-W. (2011). The moderating effect of customer perceived 
value on online shopping behavior. Online Information Review, 35(3), 333-359. http:// dx.doi.org/10.1108/14684521111151414.

Chang, H. H., Wang, Y.-H., \& Yang, W.Y. (2009). The impact of e-service quality, customer satisfaction and loyalty on e-marketing: Moderating effect of perceived value. Total Quality Management \& Business Excellence, 20 (4), 423-443.

Chaudhuri, A., \& Holbrook, M. B. (2001). The chain of effects from brand trust and brand affect to brand performance: The role of brand loyalty. Journal of Marketing, 65(2), 81-93.

Chen, C.-F., \& Wang, J.-P. (2016). Customer participation, value co-creation and customer loyalty e A case of airline online check-in system. Computers in Human Behavior, 62, 346-352. http://dx.doi.org/10.1016/j.chb.2016.04.010.

Chen, S.-C. (2012). The customer satisfactionloyalty relation in an interactive e-service setting: The mediators. Journal of Retailing and Consumer Services, 19(2) 202-210. doi: 10.1016/j. jretconser.2012.01.001.

Chris, F., Karen, E. F. (2005). Business to Business Marketing, Relationships, systems and communications. London, Ft Press.

Chung, K. H., \& Shin, J. I. (2010). The antecedents and consequents of relationship quality in internet shopping. Asia Pacific Journal of Marketing and Logistics, 22 (4), 473-491. DOI 10.1108/13555851011090510.

Cyr, D. (2008). Modeling website design across cultures: Relationships to trust, satisfaction and e-loyalty, Forthcoming Journal of Management Information Systems, 24(4), 47-72. doi:10.2753/ MIS0742-1222240402.

De Wulf, K., Odekerken-schroder, G., \& Iacobucci, D. (2001). Investments in consume relationships: A cross-country and cross-industry exploration. Journal of Marketing, 65(4), 33-50.
De Wulf, K., Odekerken-Schröder, G., \& Van Kenhove, P. (2003). Investments in consumer relationships: A critical reassessment and model extension. The International Review of Retail, Distribution and Consumer Research, 13(3), 245-261. https://doi.org/10.1080/0959396032000101354

Dorsch, M. J., Swanson, S. R., \& Kelly, S. W. (1998). The role of relationship quality in the stratification of vendors as perceived by customers. Journal of the Academy of Marketing Science, 26(2), 128-142.

Dwyer, F., Schurr, P., \& Oh, S. (1987). Developing buyer seller relationships. Journal of marketing, 51(2), 11-27.

Eggert, A., Ulaga, W., \& Schultz, F. (2006). Value creation in the relationship life cycle: a quasi-longitudinal analysis. Industrial Marketing Management, 35(1), 20-27.

Elliot, R. (2007). Linking e-service quality and markups: The role of imperfect information in the supply chain. Journal of Operations Management, 25(1), 14- 41 .

Fang, J. Shao, Y., \& Wen, C. (2016). Transactional quality, relational quality, and consumer e-loyalty: Evidence from SEM and fSQCA. International Journal of Information Management, 36(6), 1205-1217. http://dx.doi.org/10.1016/j. ijinfomgt.2016.08.006.

Flavián, C., Guinalíu, M., \& Gurrea, R. (2006). The role played by perceived usability, satisfaction and consumer trust on website loyalty. Information \& Management, 43(1), 1-14. http://doi. org/10.1016/j.im.2005.01.002.

Fornell, C., \& Larcker, D. F. (1981). Evaluating structural equation models with unobservable variables and measurement error. Journal of Marketing Research, 18(1), 39-50.

Fullerton, G. (2003). When does commitment lead to loyalty. Journal of Service Research, 5(4), 333-344. 
Giovanis, A., Athanasopoulou, P., \& Tsoukatos, E. (2015). The role ofservice fairness in the service quality - relationship quality -customer loyalty chain. Journal of Service Theory and Practice, 25(6), 744-776. https://doi.org/10.1108/JSTP11-2013-0263.

Gummerus, J., Liljander, V., Pura, M., \& van Riel, A. (2004). Customer loyalty to content-based web sites: The case of an online health-care service. Journal of Services Marketing, 18(3), 175-186.

Gundlach, G. T., Achrol, R. S., \& Mentzer, J. T. (1995). The structure of commitment in exchange. Journal of Marketing, 59(1), 78-92.

Hair F. Jr., Black, W. C., Babin, B. J., Anderson, R. E., \& Tatham, R., (1995). Multivariate Data Analysis with Readings (6th ed.). Englewood Cliffs, NJ: Prentice-Hall

Hansen, D. J., Beitelspacher, J, S., \& D. Deitz, G. (2013). Antecedents and consequences of consumers' comparative value assessments across the relationship life cycle. Journal of Business Research, 66(4), 473-479. doi: 10.1016/j. jbusres.2011.11.006.

Harris, L. C., \& Goode, M. M. (2004). The four levels of loyalty and the pivotal role of trust: A study of online service dynamics. Journal of Retailing, 80(2) 139-158, doi: 10.1016/j. jretai.2004.04.002.

Hennig-Thurau, T., Gwinner, K. P., \& Gremler, D. D. (2002). Understanding relationship marketing outcomes: An integration of relational benefits and relationship quality. Journal of Service Research, 4(3), 230-247.

Hibbard, J. D., Frederic F. B., Rajiv P. D., \& Iacobucci, D. (2001). Does relationship marketing age well? Business Strategy Review, 12(4), 29-35.

Hussien, M. I., \& Aziz, R. A. E. (2013). Investigating e-banking service quality in one of Egypt's banks: A stakeholder analysis. The TQM Journal, 25(5), 557-576. http://dx.doi. org/10.1108/TQM-11-2012-0086.

Jap, S., \& Anderson, E. (2007). Testing a life cycle theory of cooperative inter-organizational relationships: Movement across stages and performance. Management Science, 53(2), 260275. https://doi.org/10.1287/mnsc.1060.0610.

Jap, S. D., \& Ganesan S. (2000). Control mechanisms and the relationship life cycle: Implications for safeguarding specific investments and developing commitment. Journal of Marketing Research, 37(2), 227-245.

Jin, B., \& Park, Y. J. (2006). The moderating effect of online purchase experience on the evaluation of online store. Advances in Consumer Research, 33, 203-211.

Keating, B. W., Alpert, F., Kriz, A., \& Quazi, A. (2011). Mediating role of relationship quality in online services. The Journal of Computer Information Systems, 52(2), 33-41.

Kim, W. G., Lee, Y., \& Yoo, Y. (2006). Predictors of relationship quality and relationship outcomes in luxury restaurants. Journal of Hospitality and Tourism Research, 30(2), 143-169. DOI: $10.1177 / 1096348005285086$

Lau, G., \& Lee, S. (1999). Consumer's trust in a brand and the link to brand loyalty. Journal of Market-Focused Management, 4(4), 341-370.

Lichtenstein, S., \& Williamson, K. (2006). Understanding consumer adoption of internet banking: An interpretive study in the Australian banking context. Journal of Electronic Commerce Research, 7(2), 50-66.

Levy, S. (2014). Does usage level of online services matter to customers' bank loyalty? Journal of Services Marketing, 28(4), 292-299. doi:http:// dx.doi.org/10.1108/JSM-09-2012-0162. 
Luarn, P., \& Lin, H.-H. (2003). A customer loyalty model for e-service context. Journal of Electronic Commerce Research, 4(4), 156-167. https://doi.org/10.1108/08876040410536486.

Luo, J., Ba, S., \& Zhang, H. (2012). The effectiveness of online shopping characteristics and well-designed websites on satisfaction. MIS Quarterly 36(4), 1131-1144, https://ssrn.com/ abstract $=2606012$.

Maulad Musa, N. A. (2009). The Impact of Relationship Marketing on Customer Loyalty in the Banking Sector (Masters thesis). Universiti Utara Malaysia, Malaysia.

McKnight, D. H., Choudhury, V., \& Kacmar, C. (2002). Developing and validating trust measures for e-commerce: An integrative typology. Information Systems Research, 13)3(, 227-359.

Meyers, L. S, Gamest. G., \& Goarin, A. J. (2006). Applied multivariate research, design and interpretation. London: Thousand oaks.

Mohsin B. M., \& Aftab, M. (2013). Incorporating attitude towards Halal banking in an integrated service quality, satisfaction, trust and loyalty model in online Islamic banking context. International Journal of Bank Marketing, 31(1), 1-116.

Moorman, C., Zaltman, G., \& Deshpanede, R. (1992). Relationship between providers and users of market research: The dynamics of trust within and between organizations. Journal of Marketing Research, 29(3), 314-328.

Mukherjee, A., \& Nath, P. (2007). Role of electronic trust in online retailing A re-examination of the commitment-trust theory. European Journal of Marketing, 41(9-10), 1173-1202. doi: 10.1108/03090560710773390.

Naoui, F. B., \& Zaiem, I. (2010). The impact of relationship quality on client's loyalty: An application in the parapharmaceutical industry. International Journal of Pharmaceutical and
Healthcare Marketing, 4(2), 137 - 156. https:// doi.org/10.1108/17506121011059759

Nunnally, J. C., \& Bernstein, I. H. (1994). Psychometric Theory (3rd ed.). New York: McGrawHill.

Nusair, K. K., Bilgihan, A., Okumus, F., \& Cobanoglu, C. (2013). Generation Y travelers' commitment to online social network websites. Tourism Management, 35, 13-22. doi: https://doi. org/10.1016/j.tourman.2012.05.005.

Oliva, T. A., Oliver, R. L., \& MacMillan, I. C. (1992). A catastrophe model for developing service satisfaction strategies. Journal of Marketing, 56(3), 83-95.

Ozen, H. (2015). Online relationship quality: Does it increase repurchase intention from private shopping sites? International Journal of Academic Research in Business and Social Sciences, 5(7), 300312. doi: http://dx.doi.org/10.6007/IJARBSS/ v5-i7/1742.

Palmatier, R. Houston, M. B. Dant, R., \& Grewal, D. (2013). Relationship velocity: Toward a theory of relationship dynamics. Journal of Marketing, 77(1), 13-30.

Palmatier, R. W., Dant, R. P., Grewal, D., \& Evans, K. R. (2006). Factors influencing the effectiveness of relationship marketing: A metaanalysis. Journal of Marketing, 70(4), 136-153. doi: http://dx.doi.org/10.1509/jmkg.70.4.136.

Papassapa, R., \& Miller, K. E. (2007). Relationship quality as a predictor of B2B customer loyalty. Journal of Business Research, 6O(1), 21-31, https:// doi.org/10.1016/j.jbusres.2005.11.006.

Park, C., \& Kim, Y. (2003). Identifying key factors affecting consumer purchase behaviour in an online shopping context. International Journal of Retail \& Distribution Management, 31(1), 16-29. doi https://doi.org/10.1108/09590550310457818. 
Pengnate, S., Sarathy, R. (2017). An experimental investigation of the influence of website emotional design features on trust in unfamiliar online vendors. Computers in Human Behavior, 67, 4960. http://dx.doi.org/10.1016/j.chb.2016.10.018

Polites, G. L., Williams, C. K., Karahanna, E., \& Seligman, L. (2012). A theoretical framework for consumer e-satisfaction and site stickiness: An evaluation in the context of online hotel reservations. Journal of Organizational Computing and Electronic Commerce, 22(1), 1-37. http:// dx.doi.org/10.1080/10919392.2012.642242.

Rafiq, M., Fulford, H., \& Xiaoming, Lu. (2013). Building customer loyalty in online retailing: The role of relationship quality. Journal of Marketing Management, 29(3-4), 494-517. doi: 10.1080/0267257X.2012.737356.

Rahman, M. A., \& Ramli, M. F. (2016). The influence of relationship quality on customer loyalty in the dual-banking system in the northern states of peninsular Malaysia. Procedia-Social and Behavioral Sciences, 219 (31), 606-613. https://doi. org/10.1016/j.sbspro.2016.05.040.

Reichheld, F. F., \& Phil, S. (2000). E-Loyalty: Your secret weapon on the web. Harvard Business Review, 78, 107-13.

Rexha, N., Kingshott, R. P. J., \& Shang, A. S. Aw (2003). The impact of the relational plan on adoption of electronic banking. Journal of Services Marketing, 17(1), 53-67

Ribbink, D., van Riel, A. C. R. Liljander, V., \& Streukens, S. (2004). Comfort your online customer: Quality, trust and loyalty on the internet. Managing service quality. $A n$ International Journal, 14(6), 446 - 456. http:// dx.doi.org/10.1108/09604520410569784.

Roberts, K., Varki, S., \& Brodie, R. (2003). Measuring the quality of relationships in consumer services: An empirical study. European Journal of Marketing, 37(1/2), 169-196. http:// dx.doi.org/10.1108/03090560310454037.
Safa, N. S., \& Ismail, M. A. (2013). A customer loyalty formation model in electronic commerce. Economic Modelling, 35, 559-564. http://dx.doi. org/10.1016/j.econmod.2013.08.011.

Sahney, S., Ghosh, K., \& Shrivastava, A. (2013). Conceptualizing consumer "trust" in online buying behavior: an empirical inquiry and model development in Indian context. Journal of Asia Business Studies, 7(3), 278 - 298. http://dx.doi. org/10.1108/JABS-Jul-2011-0038.

Sampaio, C. H., Ladeira, W. J., \& Santini, F. D. O. (2017). Apps for mobile banking and customer satisfaction: A cross-cultural study. International Journal of Bank Marketing, 35 (7), 1133-1153.

Sanchez-Franco, M. J. (2009). The moderating effects of involvement on the relationships between satisfaction, trust and commitment in e-banking. Journal of Interactive Marketing, 23(3), 247-258.

Sharifi, S. S. \& Esfidani, R. M. (2014). The impacts of relationship marketing on cognitive dissonance, satisfaction, and loyalty. International Journal of Retail \& Distribution Management, 42(6), 553-575. https://doi.org/10.1108/ IJRDM-05-2013-0109.

Shin, J. I., Chunga, K. H., Ohb, J. S., \& Leec, C. W. (2013). The effect of site quality on repurchase intention in internet shopping through mediating variables: The case of university students in South Korea. International Journal of Information Management, 33(3), 453-463. http://dx.doi. org/10.1016/j.ijinfomgt.2013.02.003.

Smith, B. (1998). Buyer-seller relationship: Bonds, relationship management, and sex type. Canadian Journal of Administrative Sciences, 15(1), 76-92.

Suh, B., \& Han, I. (2002). Effect of trust on customer acceptance of internet banking. Electronic Commerce Research and Applications, 1(3-4), 247-263. 
Tabachnick, B. G., \& Fidell, L. S. (1996). Using multivariate statistics (3rd ed.). Boston: Allyn and Bacon.

Toufaily, E., \& Pons, F. (2017). Impact of customers' assessment of website attributes on e-relationship in the securities brokerage industry: A multichannel perspective. Journal of Retailing and Consumer Services, 34 (2017), 58-69. http:// dx.doi.org/10.1016/j.jretconser.2016.09.011.

Verhoef, P., Franses, H. P., \& Hoekstra, J. C. (2002). The effect of relational constructs on customer referrals and number of services purchased from a multiservice provider: Does age of relationship matter? Journal of the Academy of Marketing Science, 30(3), 202-216.

Vesel, P., \& Zabkar, V. (2010). Relationship quality evaluation in retailers' relationships with consumers. European Journal of Marketing, 44(9-10), 13341365. doi 10.1108/03090561011062871.

Walsh, G., Hennig-Thurau, T., Sassenberg, K., \& Bornemann, D. (2010). Does relationship quality matter in e-services? A comparison of online and offline retailing. Journal of Retailing and Consumer Services, 17(2), 130-142.

Wang, W. T., Wang, Y. S., \& Liu, E. R. (2016). The stickiness intention of group-buying websites: The integration of the commitment-trust theory and e-commerce success model. Information of Management, 53(5), 625-642. http://dx.doi. org/10.1016/j.im.2016.01.006.

Wang, L., Law, R., Guillet, B. D., Hung, K., \& Fong, D. K. C. (2015). Impact of hotel website quality on online booking intentions: E Trust as a mediator. International Journal of Hospitality Management, 47, 108-115. http://dx.doi. org/10.1016/j.ijhm.2015.03.012.

Wang, W., Liang, C. \& Wu, Y. (2006). Relationship bonding tactics, relationship quality and customer behavioural loyalty-behavioural sequence in Taiwan's information service industry. Journal of Service Research, 6(1), 31-57.

Wilson, David T. (1995). An integrated model of buyer-seller relationships. Journal of the Academy of Marketing Science, 23(4), 335-45.

Yang, Z., \& Peterson, R. (2004). Customer perceived value, satisfaction, and loyalty: The role of switching costs. Psychology and Marketing, 21(10), 799-822, https://doi.org/10.1002/ mar.20030

Yu, T. W., \& Tung, F. C. (2013). Investigating effects of relationship marketing types in life insurers in Taiwan. Managing Service Quality, 23(2), 111-130. http://dx.doi. org/10.1108/09604521311303408.

Zhang, J. Z., Watson IV, G. F., Palmatier, R. W., \& Dant, R. P. (2016). Dynamic relationship marketing. Journal of Marketing, 80(5), 53-75. https://doi.org/10.1509/jm.15.0066

Zhang, R., Li, G., Wang, Z., \& Wang, H. (2016). Relationship value based on customer equity influences on online group-buying customer loyalty. Journal of Business Research, 69(9), 3820-3826. http://dx.doi.org/10.1016/j. jbusres.2015.12.074. 


\section{Appendix}

\section{Questionnaire}

Dear respondent,

I am undertaking a research project as part of my $\mathrm{PhD}$ requirement at the Islamic Azad University / Department of Business Administration. This project is under the supervision of Dr. Samad Aali. The project aims to develop a model of dynamic relationship marketing in the context of customer perceptions of online banking services.

On the following pages, you will be presented with a series of questions about your relationship with this bank. Please note that the questions are on both sides of the paper. Your answers will of course remain completely confidential. Please answer each question as honestly as you can, and note that there are no right or wrong answers. A quick response is generally the most useful. The questionnaire should not take you more than about 7 minutes to complete. The survey data will be used for analysis only, and the final overall results will be used for academic research purposes.

Thank you in advance for your assistance in this project.

Regards,

Akram GharePasha

Ph. D. Student of Business Management

Respondent's general information

Are you?

\%o Male \%o Female

To which of the following age groups do you belong?

\%o Up to 20 \%o 21-30 \%o 31-40 \%o 41-50 \%o 51-60 \%о 61+

What is your highest educational qualification?

\%o High school \%o Diploma \%o Associate Degree \%o Bachelor \%o Master's and Doctorate

Please consider one of the banks whose online services you use and answer the following questions accordingly.

Name of the bank considered: ......

Usually, the relationship between a customer and a firm, such as a bank, develops over time. The following options show different stages of the evolution of a relationship. Please select an option that best describes your current relationship with the bank.

- Relationship recognition stage: Both me and the bank are identifying and evaluating the consistency of our goals with each other and evaluating honesty and performance. It also seems that for this to work in the longterm, there are benefits, responsibilities, and potential commitment.

- Relationship development stage: Both me and the bank receive appropriate benefits from having a relationship, and the level of satisfaction and trust between us is growing, as the parties tend to have a long-term relationship.

- Relationship preservation stage: We have worked together for a long time, and this relationship continues, so that the parties have a long-term relationship, are completely satisfied, and receive plenty of benefits.

- Relationship decline stage: One party or both is/are dissatisfied with the relationship, and while considering alternatives, we're thinking of reducing or ending this relationship.

Here are some statements concerning your perceptions of this bank and the interactions you have with it. Please rate how much you agree or disagree with each statement by circling one number on each line. 


\begin{tabular}{|c|c|c|c|c|c|c|c|}
\hline \multirow{2}{*}{$\begin{array}{l}\text { Statement } \\
\text { 1- I trust the information that is provided in the online environment of this bank }\end{array}$} & \multicolumn{3}{|c|}{$\begin{array}{c}\text { strongly } \\
\text { disagree }\end{array}$} & \multirow[b]{2}{*}{4} & \multirow[b]{2}{*}{5} & \multicolumn{2}{|c|}{$\begin{array}{c}\text { strongly } \\
\text { agree }\end{array}$} \\
\hline & 1 & 2 & 3 & & & 6 & 7 \\
\hline 2- I trust the promises that the bank makes in the online environment & 1 & 2 & 3 & 4 & 5 & 6 & 7 \\
\hline 3- I trust the e-services that the bank provides & 1 & 2 & 3 & 4 & 5 & 6 & 7 \\
\hline $\begin{array}{l}\text { 4- I suppose that if there were any problems in the online services, the bank } \\
\text { would do its best to solve them }\end{array}$ & 1 & 2 & 3 & 4 & 5 & 6 & 7 \\
\hline $\begin{array}{l}\text { 5- I am sure that the transactions performed via the online services provided by } \\
\text { the bank are free of error }\end{array}$ & 1 & 2 & 3 & 4 & 5 & 6 & 7 \\
\hline 6- The e-services promised by this bank are always provided & 1 & 2 & 3 & 4 & 5 & 6 & 7 \\
\hline 7- I feel the e-services of this bank are a part of my life & 1 & 2 & 3 & 4 & 5 & 6 & 7 \\
\hline 8- I am dependent on the e-services of this bank to do my banking tasks & 1 & 2 & 3 & 4 & 5 & 6 & 7 \\
\hline 9- Stopping using the e-services of this bank would be too difficult for me & 1 & 2 & 3 & 4 & 5 & 6 & 7 \\
\hline $\begin{array}{l}\text { 10- If I decided to stop using the e-services of this bank then managing my } \\
\text { financial tasks would be difficult }\end{array}$ & 1 & 2 & 3 & 4 & 5 & 6 & 7 \\
\hline 11- I am satisfied doing my banking tasks through the e-services of this bank & 1 & 2 & 3 & 4 & 5 & 6 & 7 \\
\hline 12- The e-services of this bank have fulfilled my expectations & 1 & 2 & 3 & 4 & 5 & 6 & 7 \\
\hline 13- I am satisfied with my decision to use the e-services of this bank & 1 & 2 & 3 & 4 & 5 & 6 & 7 \\
\hline 14- I encourage my friends and relatives to use the online services of this bank & 1 & 2 & 3 & 4 & 5 & 6 & 7 \\
\hline 15- I mention the positive e-service options of this bank to other people & 1 & 2 & 3 & 4 & 5 & 6 & 7 \\
\hline 16- I prefer using the e-services of this bank to those of other banks & 1 & 2 & 3 & 4 & 5 & 6 & 7 \\
\hline 17- I intend to use the e-services of this bank in the future & 1 & 2 & 3 & 4 & 5 & 6 & 7 \\
\hline 18- I doubt I'll change bank as long it continues providing its e-services & 1 & 2 & 3 & 4 & 5 & 6 & 7 \\
\hline $\begin{array}{l}\text { 19- Whenever I need banking services the e-services of this bank are my first } \\
\text { choices }\end{array}$ & 1 & 2 & 3 & 4 & 5 & 6 & 7 \\
\hline
\end{tabular}




\section{Authors:}

1. Akram Garepasha, Doctor of Business Management (Marketing Management), Tabriz Branch, Islamic Azad University, Tabriz, Iran.

E-mail: a.garepasha@gmail.com

ORCID

(iD) 0000-0003-0560-675X

2. Samad Aali, Doctor of Business Management (Marketing Management), Tabriz Branch, Islamic Azad University, Tabriz, Iran.

E-mail: samad.aali@iaut.ac.ir

ORCIID

(iD) 0000-0003-3890-2192

3. Alireza Bafandeh Zendeh, Doctor of Industrial Management (System Management), Tabriz Branch, Islamic Azad University, Tabriz, Iran.

E-mail: bafandeh@iaut.ac.ir

ORCID

(iD) 0000-0002-7687-6055

4. Soleyman Iranzadeh, Doctor of Industrial Management (Production Management), Tabriz Branch, Islamic Azad University, Tabriz, Iran.

E-mail: iranzadeh@iaut.ac.ir

ORCID

(iD) 0000-0001-9220-5166

\section{Contribution of each author}

\begin{tabular}{|c|c|c|c|c|}
\hline Contribution & $\begin{array}{c}\text { Akram } \\
\text { Garepasha }\end{array}$ & $\begin{array}{c}\text { Samad } \\
\text { Aali }\end{array}$ & $\begin{array}{c}\text { Alireza } \\
\text { Bafandeh } \\
\text { Zendeh }\end{array}$ & $\begin{array}{l}\text { Soleyman } \\
\text { Iranzadeh }\end{array}$ \\
\hline 1. Definition of research problem & $\sqrt{ }$ & & $\sqrt{ }$ & \\
\hline 2. Development of hypotheses or research questions (empirical studies) & $\sqrt{ }$ & & $\sqrt{ }$ & \\
\hline \multicolumn{5}{|l|}{ 3. Development of theoretical propositions (theoretical work) } \\
\hline 4. Theoretical foundation/ Literature review & $\sqrt{ }$ & $\sqrt{ }$ & & \\
\hline 5. Definition of methodological procedures & & & $\sqrt{ }$ & \\
\hline \multicolumn{5}{|l|}{ 6. Data collection } \\
\hline 7. Statistical analysis & $\sqrt{ }$ & $\sqrt{ }$ & & $\sqrt{ }$ \\
\hline 8. Analysis and interpretation of data & & & & $\sqrt{ }$ \\
\hline 9. Critical revision of the manuscript & & & $\sqrt{ }$ & \\
\hline 10. Manuscript writing & $\sqrt{ }$ & $\sqrt{ }$ & & \\
\hline 11. Other (please specify which) & & & & \\
\hline
\end{tabular}

